\title{
Quality labels and institutional density in the agro-food sector: the case of Andalusia (Spain)
}

\author{
López-Moreno, I. ${ }^{1}$, Aguilar-Criado, E. ${ }^{2}$, Lozano-Cabedo, C. ${ }^{3}$, Pérez-Chueca, A. ${ }^{2}$ \\ ${ }^{1}$ Instituto de Ciencias Agropecuarias y Rurales, Universidad Autónoma del Estado de México. Campus El \\ Cerrillo, Piedras Blancas, Carretera Toluca - Ixtlahuaca Km. 15,5, México. \\ ${ }^{2}$ Departamento de Antropología Social, Universidad de Sevilla. C/ María de Padilla s/n. Sevilla, España. \\ ${ }^{3}$ Departamento de Sociología II, Universidad Nacional de Educación a Distancia. C/ Obispo Trejo s/n. \\ Madrid, España.
}

*Corresponding author: ignacio.lopezmoreno@gmail.com

Received: 06 April 2015

Accepted: 20 May 2015

\begin{abstract}
Short title: Quality labels and institutional density in the agro-food sector of Andalusia

This paper analyses the gradual increase on the use of quality labels in rural areas of Europe and the effect of Institutional Density (ID) over them within the agro-food sector. This producer's strategy is related to three different but related processes: i) changes in the global markets, ii) new consumer patterns, iii) transformation of the rural policies. Such scenario partly explains the increase of labelling food products to add value as an economic strategy in rural areas, but not their success or failure. The contribution of this paper is to analyse representative cases of two different quality food labels: Protected Designation of Origin (PDO) and Organic Agriculture (OA) in relation to the level of ID that supported their implementation. We chose Andalusia (Spain) due to the economic centrality of its agrofood sector and for being one of the European areas with greater presence of development agencies. The data was collected during fieldwork, and quantitative and qualitative techniques were implemented.
\end{abstract}

Keywords: Food quality, rural development, institutional density, Andalusia, Spain

\section{Introduction}

The increasing implementation of quality food labels schemes represents a new trend in European rural areas. This tendency is partly due to the overexposure of consumers to the unpleasant consequences of the agro-industrial model - such as the mad cow disease or water pollution - in the mass media, which has increased risk perception on a global level (Beck, 1992; Adam et al., 2000; Levenstein, 2012). This information opened up public debates on production and distribution systems as well as the control systems which guarantee the safety of the products. One of the outcomes of this new reality is that consumers are willing to buy food produced in specific ecosystems by local know-how and embedded in local and national history; these products are perceived as safer, more natural and better quality (Espeixt, 1996; Nygard and Storstad, 1998).
This increase is also part of a new economy rooted in a new set of values, which is creating a transitional movement known as "quality turn" (Ploeg et al., 2000; Goodman, 2003, 2004; Ploeg and Renting, 2004; Sonnino and Marsden, 2006; López y Aguilar, 2013), implying a slow but steady switch from mass production agriculture to quality production, and redefining the function of rural areas in Europe. The new European rural development policies facilitate these kinds of quality certification initiatives, as they offer new opportunities for producers and institutions to unfold their projects. The appearance and later unfold of these certifications is related with the territorial focus of rural development policies that started up in 1992. This approach redefined "territory as support" to "territory as a resource", linking new initiatives with local 
culture, image and identity (Esparcia, 2000; Aguilar, 2007; Lozano, 2011).

The proliferation of distinguishing signs with varied specifications (PDO, Fair Trade, OA, etc.) is the subject of a wide range of studies. Some scholars study the promotion of these food products with the new rural economy, related to the producers' economic strategies. These strategies are considered feasible for reducing farming surpluses, boosting the less competitive, poorer regions socioeconomically, and providing small farms and companies with a tool to differentiate their products and compete in global markets (Knickel and Renting, 2000; Miele and Pinducciu, 2001; Banks and Marsden, 2001; Pugliese, 2001; Tregear et al., 2007; Ploeg and Marsden, 2008). The role of regional food in rural development projects has also been analysed by other scholars in order to understand its potential (Bessiere, 1998; Murdoch et al., 2000; Marsden and Smith, 2005; Lozano, 2011; López y Aguilar, 2012; López, 2014; López y Pérez, 2014). These approaches highlight the capacity this production has to activate other assets in the territory and thereby boost the economic, social and cultural benefits of these actions locally. This could lead to the emergence of "nested markets" (Costanigro et al., 2009). Other lines of work have revealed its importance in improving the relation between agriculture and the environment (Kaltoft, 1999), the positive impact it has on reducing contamination and its contribution to creating more sustainable farming systems (Rigby and Cáceres, 2001). On a more micro-social level there are other views focused on the relation between food and territory. These approaches empirically deal with a number of cases of local production systems and their relation with these strategies. They highlight the importance of "know-how" (Requier-Desjardins, et al. 2003; Muchnick et al., 2007; Aguilar et al., 2009; Bowen, 2010), and the creation of horizontal and vertical networks for internal coordination of local actors implementing these kind of strategies (Murdoch, 2000; Boucher et al. 2006; Tregear et al., 2007; Lozano y Aguilar, 2012). There is another line of work which analyses the effects of these labels in the "Global Value Chain". In this case, the quality labels are understood as ways of governance (Ponte, 2009), and there are three main interpretations: as "drivenness" (Gereffi and Korzeniewicz, 1994), as “coordination” (Gereffi et al. 2005), and as "normalisation" (Gibbon and Ponte 2005). Finally, there is the approach of consumer behaviour studies, which focus on consumers' response to products with quality labels (Wierenga et al., 1997; Bonnet and Simoni, 2001; Laroche et al., 2001; Solomon et al., 2006; Paul and Rana, 2012).
The aspect which has received less attention is the link between the origin and evolution of these quality food products and the institutional contexts where they are designed and created. Regarding this approach, the analyses carried out from the point of view of institutional economy are especially relevant (Smelser and Swedberg, 1994; Hodgson, 1998). As a branch of economic sociology, it regards the economy as something much deeper than just a system of companies and markets based on rational and standard regulations, it understand economy as: " $a$ composition of collective influences which make up the actions of individuals, and as a diversified entity which follows a dependent path due to the cultural and socio-institutional influences it has inherited" (Amin, 1998). Therefore, we are especially interested in the conceptualization that this discipline has on the institutions defined "collective forces". When they interact, they boost the economy, thereby rediscovering the potential that institutions have for economy. These collective forces include both formal (laws, regulations and organizations) and informal institutions (habits, rules and social values).

To carry out the analysis of these institutional frameworks linked with quality production labelling initiatives, we use the ID concept (Amin and Thirft, 1993). This concept includes organizational, socio-cultural and economic aspects of a given reality. The ID includes four basic main aspects: (1) the relation and interinstitutional synergy, (2) the collective representation by a large number of entities, (3) the configuration of a common project and, finally, (4) a series of shared rules and values. The presence of high institutional density can have positive effect, such as the creation of stronger legitimacy, fosters trustworthy relations, stimulates business capacity, or consolidates the rooting of economic activity in the local environment. Some authors emphasize that the institutional contribution is not only limited to the existence of institutions or formal rules, but also to the soft institutions that stimulate the development of a diffuse business capacity, based on a set of codes of practice, support and customary rules accepted by all. From this point of view, soft institutions are the key to economic growth (Streeck, 1991).

The objective of this article is to study the influence of ID on the achievement of successful creation of local quality schemes, such as PDOs or OA. In order to achieve this objective we focus on two key types of quality labels: Protected Designations of Origin (PDO) and Organic Agriculture (OA). This article divided in another three parts, in the next part we explain the methodology followed during our research. Later, we analyse and discuss the benefits and risks of ID 
for labelling strategies in Andalusia. We close with a summary of the findings and recommendations for further research.

\section{Material and methods}

Quality labels are, from an analytical point of view, new "institutional agreements". This means that there are new rules and requirements for the actors involved in producing, processing and consuming the labelled products. The process of setting these new rules is an exercise of (1) rethinking and (2) re-designing the reality where the product is embedded. Quality labels, for the actors that create them also are economic strategies, which seek to market their products with a better position in the globalized economy. We seek to understand complex processes from an internal and analytical point of view; hence, we chose an actor-oriented approach to study this new tendency (Long, 2001). Our research was divided into three different phases: documents and literature review, fieldwork, and data analysis. We implemented qualitative and quantitative techniques during long periods of fieldwork in two observational units in Andalusia: Sierra de Cádiz y Sierra de Segura (Jaén). We choose these units for two different reasons: (1) their long experience in rural development policy implementation, and (2) the importance of quality labelling strategies in their agro-food industry.

One of the key aspects of our research was to choose the right categories of actors. We identified three groups: (1) technical managers and politicians, (2) local associations, and (3) rural entrepreneurs ${ }^{1}$. Technical managers and politicians are those who manage and supervise the implementation of rural development projects and programmes, such as LEADER+. Their position gives them first-hand information about the resources and needs of local population, and entrepreneurs in particular. The representatives of associations and societies are involved in the implementation of these labels and work as a platform for the previous group. Rural entrepreneurs are the most important group; they are the main actors of the analysed processes. In this category we have included those who are involved in projects related to labelling strategies, those who applied for them, and those who did not participate in the project or apply for them.

A total number of 127 semi-structured interviews were carried out: 79 to rural entrepreneurs, 26 to technical managers/politicians and 22 to associations. Participant observation complemented the data collection phase and

\footnotetext{
${ }^{1}$ These categories of local actors also answer to the new logic of rural governance (Wiskerke et al., 2003; Pérez y Aguilar, 2013), and to the requirements of the interface analysis (Long, 2001).
}

supported our later interpretation of fieldwork data. This technique gives a better insight and generated the trust needed to obtain the information during the formal interviews.

\section{Results and discussion}

\subsection{Quality agri-food products and labelling strategies}

The promotion and protection of local food products through quality labelling strategies is a practice with a long tradition in the Mediterranean countries. In fact, labelling systems, such as Geographical Indications (GIs), were already regulated in southern countries in the 1920s. These early strategies aimed to protect and preserve specific products from particular areas. The regulation was first designed for the wine sector and later expanded to other products. Portugal, France, Spain and Italy were, and still are, pioneers in this kind of regulation. Indeed, it was the admission to the EU of southern countries in the eighties that increased pressure for $\mathrm{EU}$ regulations $^{2}$. In 1992, the first Quality Scheme framework came into force, and it was reformed in 2006 and 2012. PDOs are currently governed by the Regulation (EU) No 1151/2012 of the European Parliament and the Council of 21 November 2012 on quality schemes for agricultural products and foodstuffs.

It is important to point out that this strategy has gained great importance in Spain and this fact is directly related to the new alimentary context and to the role of the new rural territories. GIs are the most acknowledged quality food labels in Europe, and the products with these labels are subjected to very strict Codes of Practices. These codes seek to perverse and assure that the products incorporate the inherent qualities attributed to their specific territories and "know-how". These qualities can be either natural (climate, ecosystem, geography) or cultural (local techniques, traditional knowledge, history). According to the EU current regulation, it is the final amount of these specific, intangible characteristics that makes a product suitable for protection.

OA is another certification with a long tradition in Europe. Spain was the third country in the EU to pass a specific law on OA in 1988. Three years later, the EU also approved a common regulation (CEE 2092/91). In 2007 the European Council of Agricultural Ministers approved the Council Regulation (EC) No. 834/2007 of 28 June 2007 on organic production and labelling of organic

\footnotetext{
${ }^{2}$ According to some scholars (Ventura et al. 2006), these new admissions also changed the CAP perspective, increasing support on Mediterranean products. Before this, the CAP used to support products which were characteristic of northern European countries, such as cereals and livestock.
} 
products $^{3}$. This European framework defines the requirements which products and foodstuff have to meet in order to be suitable for organic certification. In relation to this label, it is important to point out that quality is not defined by the link with the territory, but with a wide variety of specific momentous previous to consumption: agricultural inputs and techniques, transformation, inspection protocols, marketing, etc. This legislation mainly aims to guarantee quality and traceability of organic products and foodstuff. The label of OA has achieved international reputation in the last decades, with Spain being an active participant in its growth. Nowadays, Spain has the $7^{\text {th }}$ largest organic farming area in the world and the $1^{\text {st }}$ largest organic farming area in Europe (Willer and Kilcher, 2011).

\subsection{Quality food labelling strategy in Andalusia}

Labelling quality food products in Andalusia is of the new set of rural development practices that have risen over the whole continent (Ploeg et al., 2002). Local Actions Groups (LAGs) and public administrations support and use them as tools for that.

Olive oil PDOs are paradigmatic examples of this institutional support. The first generation of PDOs in this sector was created at the beginning of the 80s. They were limited to mountainous areas because these certifications were conceived as a strategy to make less productive olive trees profitable (Sanz and Macias, 2005). It is important to notice that in most cases the same traits that limits olive grove productivity may increase the quality of the oil, e.g., the location of the olive trees in highlands gives them an optimum soil draining, good product exposure, which reduce the risk of plagues. A rural entrepreneur from the Sierra de Segura, the first Andalusian territory to get an olive oil PDO in 1979, told us why they opted for this strategy: "We couldn't compete with other olive tree production areas where the average production is double or triple compared to ours and the costs are half, 50\%. So, it was impossible to compete. Therefore, we had to compete in another sector, which was the quality sector"

(President of Olive Oil Cooperative, 56 years old).

This panorama began to change substantially from the year 2000, 14 new PDOs were approved by the Spanish regulations since them. This meant that in 15 years, the area registered under this label increased by five. This large increase of olive oil PDOs is related to the reorientation process of the

\footnotetext{
3 The authors are aware that a new regulation on organic farming and labelling is currently under study within the EU, however, we do not consider it because it was not enforced at the time of our research.
}

CAP towards multi-functionality and the promotion of quality production and, to the implantation of the EC LEADER Initiatives. Since the implementation of LEADER in 1991, this programme has changed the institutional map and administrative approach to rural areas in Andalusia. Nowadays, Andalusia is divided into 52 counties or rural development areas, where 52 LAGs coordinate and promote rural development projects and initiatives. These new actors were conceived as territorial coordinators and promoters, and they have unfolded a high level of institutional thickness in rural areas (Amin and Thrift, 1995).

The importance of the agro-food sector in Andalusia and the appearance of the "quality turn" encouraged the LAGs to become interested in promoting GIs to create added value for the local economy of their territories. LAGs are involved in the establishment and later development of olive oil PDOs in different ways. On the one hand, they have financially supported Regulatory Boards and have helped them with new infrastructures, marketing, advertising and coverage. On the other hand, they have led the process in most cases, and have been able to mobilize and coordinate different local actors. In some cases, as Sanz and Macías (2005) explained, the institutional network created to support the establishment of a PDO can go even further than the LAG, including the administration of a natural protected area or a university.

Olive Oil PDO Sierra de Cádiz is one of the clearest examples of the close connection and commitment between LAGs and PDO Regulatory Boards. This group belongs to the first generation of LAGs in Andalusia, and their activities started up with the LEADER I Initiative. They encouraged the creation of this PDO because they understood that PDOs increase local producers' profits by adding value through exclusive territorial monopoly. They created an association to work as a platform to apply for the PDO for the area, and brought everyone together to negotiate the conditions and characteristics the olive oil would have. Even more, they manage to get involve the municipality of Olvera in the project, which gave free access to a public building for the laboratories and office of the PDO. At the same time, the LAG has approved modernisation projects for every mill that is part of the PDO using the LEADER Initiatives. In addition, since the creation of the PDO in 2002, the LAG's manager is also the president of the Regulatory Board. In this sense, it can be said that LAG assumed most of the "Transaction Costs" (Harris et al., 1995) of this PDO, facilitating the process for local producers. Many of the actors interviewed have made comments about this point: "It would have been impossible for us to get it 
alone. Without them (LAG) and the Regional Minister of Agriculture we would never have gotten our PDO” (PDO technical manager, 33 years old).

However, the current reality of the PDO Sierra de Cádiz is uncertain. On the one hand, the sector is facing strong competition as the number of PDOs increases in Andalusia and the rest of Spain. On the other hand, farmers do not feel compensated by the rise in their costs of production introduced to assure the quality of the oil. This is why there has been an increase in the number of PDO Sierra de Cádiz companies who have abandoned the Regulatory Board and returned to the conventional system.

Another clear example of the link between these actors, the PDOs and the territory development agencies are the olive oil PDOs Sierra Sur and Campiñas de Jaén. These PDOs achieved state acknowledgement in 2006 thanks to a campaign carried out by their LAGs and the interest of the producers in the area to get a PDO. We should point out that, unlike other PDOs in the province of Jaén, these were not located in mountainous regions but in the countryside, which means that the olive crops were more productive and their level of technological advancement and intensification was higher. However, the territorial names established for both PDOs Sierra Sur and Campiñas de Jaén did not previously exist or refer to any specific, historical or geographically constituted territory and both initiatives were created by their respective LAGs. However, the EU rejected the request of Olive oil PDO Sierra Sur in 2009, claiming that there was indeed dissociation between designation, territory and product. This rejection logically caused the withdrawal of the second initiative. Later on, several LAGs and the Regional Government tried to save these initiatives by unifying all the olive grove areas in Jaén under the same label -Protected Geographical Indication Aceite de Jaén- instead of the current fragmentation under different PDOs. The name of the province has been taken as a brand label, since this territory have a renowned prestige nationally and internationally, and is the largest producer in the world making up between 15 to $20 \%$ of the total production worldwide. However, this project was also abandoned since did not fulfil the regulations.

The increasing number of accepted olive oil PDO processes in Andalusia after the implementation of the LEADER Initiatives highlights the influence that this new institutional framework has on the process of quality food labelling. It is possible to talk about two different historical moments on this practice. The first moment answer to the time previous to the LAGs and the redefinition of rural development policies; the projects were led by the producers, responded to a genuine economic strategy of distinction in order to compete with other generic olive oil producers, and came from areas with a distinct historical character and a strong link between the territory and the olive oil. The second phase is characterised by the intervention and leadership of the LAGs; they led these actions and are in charge of coordinating and encouraging the farmers. The interest in having a distinctive label of territorial production led to a proliferation of these initiatives and an automatic reproduction of a model which would have needed a previous analysis of the potential of each and every case.

The situation of the PDO Sierra de Cádiz can be explained in this context. It has been the result of a local top-down initiative and a political agenda, which was facilitated by the existence of the public funding from the EU. This process shows to what extent the origin of these initiatives can be a burden to the objective of territorial development, and how dissociated can they be from their "natural" protagonist; the farmers. The process was dominated by the LAGs' interest to get a quality label that make reference to their territorial development, and they did not take into account the wiliness of the farmers to assume the challenges involved in readapting their facilities to the new standard defined by the Regulatory Board on production, packaging, marketing and sales level. In this case, the high level of ID did not support the creation of a successful local quality scheme, even more; it worked as a platform for the enforcement of political agendas that was far from the real needs of the sector. Therefore, the implementation of this kind of initiatives can be overturned when the power relationship between the actors involved is not similar.

\subsection{Labelling strategies and organic agriculture}

Andalusia plays an essential role in organic agriculture of Spain for two reasons: firstly, because the region accounts for $60 \%$ of the total Spanish certified area and more than $30 \%$ of the total producers, and there has been a continuous increase during the last decades in the number of hectares and producers. Secondly, the regional public administration showed an early interest in sector regulation and institutional support. Andalusia was the first Spanish region to define its own instrument for the control of organic production in 1991, Comité Territorial Andaluz de Agricultura Ecológica, and to make specific legislation in $1996^{4}$ to regulate this activity in the territory. This institutional support reached its highest peak with the application of two

\footnotetext{
${ }^{4}$ Order of 5th June 1996, in which regulations are passed on organic farm production and its indication in farm and food products in the Andalusian Committee of Organic Agriculture.
} 
instruments: the publication in 2002 of the Plan Andaluz de la Agricultura Ecológica 2002-2006 (PAAE) and the creation in 2004 of the Dirección General de Agricultura Ecológica (DGAE), registered in the Regional Ministry of Agriculture and Fishery.

In this way, Andalusia became the first Autonomous Community to be provided with a specific plan and its own independent entity to direct and promote organic agriculture in its territory. The DGAE promoted a series of initiatives to encourage a coordinated organic sector, which would establish links with the territory, promote producer-consumer relations through the development of short marketing channels and social consumption promotion, and encourage organic agriculture in protected areas.

To illustrate the impact these measures have had on the development and organization of the organic sector in Andalusia, we analyse the effect of this institutional framework in a specific territory: Sierra de Segura. This area is because it is one of the first territories in Spain to produce organic olive oil and because of its location in the largest Nature Park in Spain: the "Sierra de Cazorla Segura y Las Villas Nature Park”. The DGAE designed a specific plan to discover the problems and potential of the sector in this area. The first action carried out was the coordination of the different policy areas (agriculture, environment, employment, health, etc.) and the administrative levels working in the area. For the first time, a forum was established to encourage dialogue between the local population and representatives of the Nature Park, two traditionally antagonistic groups, and they agreed on a common strategy for the development of organic production in the protected area (Lozano y Aguilar, 2012). This forum also led certifies public forest pastures as organic land, which was one of the main obstacles for the development of organic livestock in this area.

It was considered necessary to adopt a holistic perspective in order to develop the organic production sector in this territory, trying to act simultaneously on all aspects of the process. On the production side, different measures were designed, not only to increase its productive capacity, but also to promote the diversification of activities and crops. The aim was to broaden the range of products in the area to create an internal market. This meant that local consumers would have access to a wide variety of foods $s^{5}$ throughout the year, without having to bring them from other parts of Andalusia. At the same time, coordination

\footnotetext{
${ }^{5}$ The main factors that block the commercial development of organic production are the limited offer of organic products, the limited distribution, and the problems found by consumers in markets.
}

was encouraged between the different sectors in order to strengthen the sector: livestock, grain and oil production, horticulture, etc.

With regard to the marketing and sale of organic products, a campaign was launched to promote domestic consumption. The first experience was the location of a "Biopunto", a sales centre in the weekly main street markets in the municipalities. Similarly, it has encouraged coordination regarding the choice of crops, in order to offer local consumers a wider range of products and a steady supply throughout the year. The second experience focused on the promotion of social consumption. In 2007, this experience began to be implemented in the area and led to the launching of menus prepared with organic food in some schools, kindergartens and in the local hospital.

All these measures have achieved an important double-purpose: to make the products visible, and to distribute them among the local population to overcome the resistance and negative stereotypes towards this production system (Lozano, 2013). This double-objective is important because encouraging consumption and increasing demand for this kind of food would solve one of the main problems of the organic sector which is marketing and selling, and could also lead conventional farmers towards conversion. From the convergence of all these projects, an association of producers and consumers has emerged in the area called "Segura-Ecológica".

Despite its short history, the results of this Plan have been quite positive. Since its application, the internal consumption of these products has increased and the certified area has grown considerably from $2,455.31$ ha in 2004 to more than 7,000 ha. There has also been a strong development in organic cattle with the incorporation of 15 stockbreeders, bringing the current number of producers to around 174 . Likewise, and through this plan, a type of social fabric has been formed around this activity and coordinated actions have been established among different actors in the territory. Moreover, measures have been implemented for the first time to actively integrate the farmers in the management of the natural resources of the Nature Park (Lozano, 2011).

Therefore, it could be said that the high density for the institutional framework is adequate in this case, given that the regional administration institutions have played a leading role in starting up the process without hidden agendas. The project has been developed and a situation of institutional density has been reached, guaranteeing the future of the initiative. In this case, a large variety of actors and territorial representatives have been involved from the beginning, forming plural institutional networks 
(administration, regional institutions, LAG, the Nature Park, producer and consumer associations, etc.). In order to do this, the former existence of an important social capital in the territory has been essential and has activated the development of the initiative (Lozano, 2012). In fact, the choice of this area by the administration for the process start-up was not a coincidence. It was chosen precisely because its critical mass and social capital were also capable of creating the necessary synergies between the different sectors of the institutional network (Wiskerke and Ploeg, 2004). This is, therefore, the first factor linked to institutional density.

The fact that the relations between the different actors were developed through coordinated actions, making the nucleus share the decisionmaking, and especially including the producers in the processes of territorial management in the Nature Park, indicates a clear participatory strategy. The process therefore acquires legitimacy, and this, in turn, strengthens trust between the actors. This line of actions enables the development of coordinated actions and synergies between actors of the network, meaning that the second requirement, necessary for the existence of the institutional density mentioned above, is met. On the other hand, it must be pointed out that the guidelines and lines of action promoted by this initiative towards the economic sector have been clear and accepted by all the network actors from the beginning. In this sense, they have set up a single development strategic plan, a common plan in which both local actors and the regional administration have been able to coordinate their interests, expectations and motivations. This is the third element sustaining institutional density.

Finally, we must point out that these actions have retrieved a tradition which already existed in the area, fostering the local know-how and thereby promoting environmentally-friendly economic activities. These matters reflect the existence of a series of shared rules and values, such as farm production and traditional stockbreeding, respect for the environment, the creation of feasible economic initiatives to encourage the rooting of the population in the area, the territorial identity of the inhabitants who support the conservation of these lands and life-styles to, in turn, conserve specific cultural features. This makes up a "corpus" of shared rules and values (soft institutions according to DI rhetoric) within this initiative which has increased its positive results. The fourth factor is therefore achieved, enabling institutional density.

The explanation for the success and ambition of this territorial development proposal, based on the organic agriculture label, can be found precisely in the combination of all the factors we have mentioned: the diversity of representative actors, the creation of networks of actors and synergies between them, the existence of a common project and the fact that they have certain shared rules and values. All these circumstances certainly make this case a paradigmatic case of institutional density, in the sense that we have mentioned at the beginning of this text (Amin and Thrift, 1993).

\subsection{The economic strategy of the distinction and the institutional support}

The institutional support on quality label strategies has led to the proliferation of these certifications in many European regions. This process has been especially present in the Objective 1 regions of the Common Agricultural Policy, which have been supported preferably by programmes and specific financing on behalf of European development policies. This has meant that the competitive advantages of the first PDOs have become more widespread and there is an increase in the competition between the PDOs of the same product in the same region, as is the case of olive oil in Andalusia. The "distinction" therefore becomes a trivialization, because the creation model of a PDO is exported and "copied", without carrying out a clear analysis of the potential and specific features of the territories where it is applied. This also creates false expectations among the groups involved and ends up producing mistrust towards the administration and their interference in local development strategies. The spread of these olive oil PDOs has especially affected the PDOs located in mountain areas, facing socioeconomic and demographic problems. They are doomed to compete on equal terms with other PDOs in areas which are far more productive and have higher profitability, which is what was happening to the PDOs Sierra Sur and Campiñas de Jaén.

In addition, this kind of actions has been unable to change the lack of control this region has on the marketing and sales of its olive oil. This structural deficiency is rather paradoxical if we take into account that it is the first production area worldwide, and it has historically left world marketing in the hands of the Italians. The PDO quality commitment has hardly had any influence in this field, because, as Langreo (2004) points out, the amount of protected olive oil in any of the existing PDOs in Spain is around 48,000 tons. Out of these, only 18,000 tons are marketed under this label, which means a mere $37 \%$ of the total amount. That is to say, the proliferation of these labels has focused on the differentiation of each territory with its own label and on reaching an advantageous position with regard to the neighbouring areas and products, neglecting a basic aspect for the sector which is the need to correct the structural dissociation between 
production and marketing. What has prevailed has been a microeconomic policy, clearly linked to the institutional framework which the different LAGs have created in Andalusia, as these are the entities which have led the production distinction process. The failure of the PDO Sierra de Cádiz is paradigmatic of this situation as it has lacked a collective vision which would have allowed it to deal with the macroeconomic situation regionally and challenge the competition from the traditional olive oil sector and the other existing PDOs in Spain.

The example of the Sierra de Segura Organic Agriculture highlights that, unlike in the previous cases, the "institutional frameworks" have brought about trust and collective actions, and have known how to give legitimacy to the process by playing a positive mediation role among the actors (Ploeg and Marsden, 2008). This case also makes it clear that this public administration initiative is not a replica of other successful models in other territories, but is a specifically designed project, based on dialogue with the local actors to define the potential and performance strategies for this territory, taking into account their resources and social-cultural elements, as propounded by the perspective of institutional economy (Amin, 1998). The territorial context serves as a framework for a local production tradition, which has ended up creating a specific production method in an area with less farming potential but with unquestionable environmental values. These values are now incorporated as an added quality element in this project. This proposal has undoubtedly managed to stimulate the business and enterprising capacity of the local actors, as key factors for sustainable economic growth.

\section{Conclusions}

This paper uses the concepts of institutional frameworks and ID to analyse the process of creation and implementation of local quality schemes for food products in Andalusia. Two labels have been studied in order to do this: the olive oil PDOs and OA and the configuration that both have adopted in two mountain territories, the Sierra de Cádiz and the Sierra de Segura, with structural problems both on economic and demographic levels (ageing, masculinisation, depopulation, difficulties to intensify farming activity). Firstly, we show how one of the factors which affects the success of these initiatives is whether there are specific institutional frameworks supporting them. This element is basic for understanding other factors, such as the coherence of these projects and the synergies created between producers, sectors and the administration, since the presence or lack of these institutional frameworks can either help or hinder these actions. We pointed out that the existence of a think ID may not be so interesting for all the local actors involved in the process. The case of the PDO Sierra de Cádiz is a good indicator of how institutional frameworks can be an obstacle for the coherence of production differentiation projects led from their LAGs. On the other hand, the case of the specialization of OA in Sierra de Segura is a clear exponent of how institutional frameworks, synergies between actors, sectors and administration have achieved the institutional density necessary to generate positive expectations of the project with an eye towards the future, despite the recent disappearance of some of these institutional networks, which is slowing down the project as a whole.

Secondly, what both cases show us is that the link between institutional intervention in the planning of territory development strategies and the expectations of local actors is essential for achieving success in a labelling strategy. When the development agencies are not the vehicle but rather lead the actions, regardless of the production sustainability and profitability, as is the case of the Sierra de Cádiz, this kind of initiatives end up being marginalized by the markets themselves. Similarly, as the local actors were not included in the design of these initiatives, they did not know the impact that being in a PDO would have on their way of approaching olive oil production. Neither did they know the challenges this would mean when dealing with the marketing of the quality product. Both factors make them abandon the project as soon as it fails to come up to their short-term economic expectations.

Thirdly, we would like to highlight that the situation of institutional dependence which many of these projects are subjected to, means a risk for the feasibility of these initiatives. In many cases, their continuity is subject to political changes and the public financing available for these programmes. This situation creates a high degree of uncertainty in many projects which are not given enough time or financing to become established. Likewise, sustained institutional dependence ends up choking the proposed enterprising spirit that the European policies are trying to promote in these territories. This is why the producers only consider new economic policies when there are programmes with specific financing. In this paper, we have presented two cases which shared a high level of institutional dependence. In the case of the PDO Sierra de Cádiz olive oil, as well as other PDOs which have been analysed, this situation is very clear because the initiative to get the quality label was promoted from the local development agencies themselves. In the Sierra de Segura, there has also been strong institutional support from the regional government, although the design of the organic 
farming actions has mostly been made by actors from the territory, according to their needs.

This situation is connected with the last idea we have put forward. Public policies are trying to achieve complex objectives for rural areas, but it is also true that institutional "overprotectiveness" is not the right path. Paradoxically, the use of financial support may also transform their entrepreneurial spirit, creating institutional dependency. In order to make this new model of production and consumption more widespread, we think that the institutions have to work on taking the whole network.

\section{Acknowledgements}

This paper is the outcome of two research projects financed by the Ministerio de Ciencia e Innovación (CSO2010-22074-C03-01), “La producción de calidad: nuevas estrategias rurales para nuevos consumidores" and (CSO201342468-P) "Las marcas de calidad en el mundo rural: nuevos retos para productores $y$ consumidores" I+D. Ministerio de Economía y Competitividad y FEDER. We also would like to aknowledge the Talentia Incentive Program of the Andalusian Regional Ministry of Economy, Innovation, Science and Employment for their finantial support. The research group Territorio, Cultura y Desarrollo (SEJ418) of the Departamento de Antropología Social (Universidad de Sevilla) is responsible of the data and analysis of this paper.

\section{References}

Adam, B., Beck, U., Loon, J.V. 2000. The risk society and beyond. Critical issues for social theory. Sage Publications, London.

Aguilar, E. 2007. Productos locales, mercados globales. Nuevas estrategias de desarrollo en el mundo rural. En: García, M. (Ed.). Perspectivas teóricas en desarrollo local. Ed. Netbiblo, A Coruña.

Aguilar, E., .Lozano, C., López., I., Pérez, A. 2009. Entre la tradición y la innovación: políticas de empleo femenino y desarrollo rural. Sociología del Trabajo 65: 111-136.

Amin, A., Thrift, N. 1993. Globalization, Institucional Thickness and local prospects. Revue d'Economie Rurale et Urbaine 3: 416-417.

Amin, A., Thrift, N. (1995). Institutional issues for the European regions: from markets and plans to socioeconomics and powers association. Economy and Society 24: 43-66.

Amin, A. (1998). La perspectiva institucionalista del desarrollo económico regional [An institutionalist perspective of the regional economic development]. Ekonomiaz, Revista Vasca de Economía 41: 68-89.

Banks, J., Marsden, T. 2001. The nature of rural development: the organic potential. Journal of Environmental Policy and Planning 3: 103-121.

Beck, U. 1992. Risk society: towards a new modernity. Sage Publications, New Delhi.

Bessiere, J. 1998. Local development and heritage. Traditional food and cousine as tourist attraction. Sociologia Ruralis 38: 21-34.

Bonnet, C., Simoni, M. 2001. Assessing consumer response to protected designation of origin labelling: a mixed multinomial logit approach. European Review of Agricultural Economics 28: 433-449.

Boucher, F., Pomeón, T., Cervantes, F., Fournier, S. 2006. Las dinámicas colectivas en dos cuencas lecheras mexicanas: Tlaxco, Tlaxcala y Tizayuca, Hidalgo (The collective dynamics of two mexican milk basin: Tlaxco, Tlaxcala and Tizayuca, Hidalgo). Revista Agroalimentaria 22: 49-64.

Bowen, S. 2010. Embedding local places in global spaces: Geographical Indications as a territorial development strategy. Rural Sociology 75(2): 209243.

Costanigro, M., McCluskey, J.J., Goemans, C. 2009. The economics of nested names: name specificity, reputation and price premia. American Association of Wine Economists, Working Paper 49.

Esparcia, J. 2000. The Leader programme and the rise of rural development in Spain. Sociologia Ruralis 40: 200-207.

Espeitx, E. 1996. Los nuevos consumidores o las nuevas relaciones entre campo y ciudad a través de los productos de la tierra [The new consumers o the new relationships between the country and the city through the land products]. Agricultura y Sociedad 80-81: 83-116.

Gereffi, G., Korzeniewicz, M. 1994. Commodity chains and global capitalism. Praeger Publishers, Westport, California.

Gereffi, G., Humphrey, J., Sturgeon, T. 2005. The governance of global value chains. Review of International Political Economy 12: 78-104.

Gibbon, P., Ponte, S. 2005. Trading down: Africa, value chains, and the global economy. Temple University Press, Philadelphia, PA.

Goodman, D. 2003. The quality turn and alternative food practices: reflections and agenda. Journal of Rural Studies 19: 1-7. 
Goodman, D. 2004. Rural Europe redux? Reflections on alternative agro-food networks and paradigm change. Sociologia Ruralis 44: 3-16.

Harris, J., Hunter, J., Lewis, C.M. 1995. The new institutional economics and third world development. Ed. Routledge, London.

Hogdson, G.M. 1998. The approach of institutional economics. Journal of Economic Literature 36: 166-192.

Kaltoft, P. 1999. Values about nature in organic farming practice and knowledge. Sociologia Ruralis 39: 39-53.

Knickel, K., Renting, H. 2000. Methodological and conceptual issues in the study of multifunctionality and rural development. Sociologia Ruralis 40: 512-528.

Langreo, A. 2004. La posición de los productos con calidad diferencial en el sistema alimentario del siglo XXI [The positon of diferenciated quality products in the food system of the XXI century]. Cuadernos de la Tierra del Agricultor y Ganadero 3: 24-30.

Laroche, M., Bergeron, J., Barbaro-Forleo, G. 2001. Targeting consumers who are willing to pay more for environmentally friendly products. Journal of Consumer Marketing 18: 503-520.

Levenstein, H. 2012. Fear of food. A history of why we worry about what we eat. The University of Chicago Press, Chicago.

Long, N. 2001. Development sociology: Actor perspectives. Ed. Routledge, London.

López, I., Aguilar, E. 2012. Las etiquetas de calidad y el desarrollo territorial: los casos del queso de oveja merina de Grazalema y la carne de cordero de Texel [Quality labels and territorial development: The cases of Merina de Grazalema Sheep Cheese and Texel Lamb Meat]. Revista de Economía Agrícola, 59 (2): 131-149

López. I., Aguilar, E. 2013. La nueva economía rural europea. Especialización territorial de calidad en la Isla de Texel y la Sierra de Cádiz [The new european rural economy. Especialization towards territorial quality in Isla de Texel and Sierra de Cadiz]. Gazeta de Antropología 29 (2): Art. 4.

López, I. 2014. Labelling the origin of food products. Towards sustainable territorial development? Ponsen \& Looijen, Eds., The Netherlands.

López, I., Pérez, E. 2014. Las Etiquetas de Calidad Agroalimentarias como herramientas de gobernabilidad y desarrollo territorial [Quality Food Labels as instrumentes of governance and territorial development]. Inguruak. Revista Vasca de sociología y Ciencia Política 57-58: 2102-2014

Lozano, C. 2011. El sabor de la naturaleza. Agricultura ecológica en Parques Naturales Andaluces. Fundación Blas Infante, Sevilla.

Lozano, C. 2012. El fomento de la integración laboral femenina en el medio rural: evaluación del impacto de los talleres de empleo en la Sierra de Segura (Jaén) [The promotion of female labour integration in rural areas: evaluation of the impact of employment workshops in Sierra de Segura (Jaen)] AGER: Revista de Estudios sobre Despoblación y Desarrollo Rural 12: 117-147.

Lozano, C., Aguilar, E. 2012. Territorialising organic production: collective actions and public policies in Andalusia. .Sviluppo Locale vol. XV: 45-66.

Lozano, C. 2013. Representaciones sociales de la agricultura ecológica en Andalucía [Social representations of organic agriculture in Andalusia]. Gazeta de Antropología 29(2): Art. 5.

Marsden, T., Smith, E. 2005. Ecological entrepreneurship: sustainable development in local communities through quality food production and local branding. Geoforum 440-451.

Miele, M., Pinducciu, D. 2001. A market for nature: linking the production and consumption of organics in Tuscany. Journal of Environmental Policy and Planning 3: 149-162.

Muchnik, J., Requier-Desjardins, D., Sautier, D., Touzard. J.M. 2007. Introduction: les systèmes agroalimentaires localisés [Introduction: the local agrofood systems). Économies et Sociétés 9: 1465-1484.

Murdoch, J. 2000. Networks - a new paradigm of rural development?. Journal of Rural Studies 16: 407-419.

Murdoch, J., Marsden, T., Banks, J. 2000. Quality, nature, and embeddedness: some theoretical considerations in the context of the food sector. Economic Geography 76: 107-125.

Nygard, B., Storstad, O. 1998. De-globalization of food markets? Consumer perceptions of safe food: The case of Norway. Sociologia Ruralis 38: 35-53.

Paul, J., Rana, J. 2012. Consumer behavior and purchase intention for organic food. Journal of Consumer Marketing 29: 412-422.

Pérez, A., Aguilar, E. 2013. Aportaciones al análisis comparativo entre modelos de desarrollo rural en Europa [Contributions of the comparative analisis between rural development models in Europe]. Gazeta de Antropología, 29 (2): Art. 02

Ploeg, J.D., Renting, H., Brunori, G., Knickel, K., Mannion, J., Marsden, T., Roest, K., Sevilla- 
Guzman, E., Ventura, F. 2000. Rural development: from practices and policies toward theory. Sociologia Ruralis 40: 391-408.

Ploeg, J.D., Banks, J., Long, A. 2002. Living countrysides. Rural development processes in Europe: The state of art. Elsevier.

Ploeg, J.D., Renting, H. 2004. Behind the Redux: A rejoinder to David Goodman. Sociologia Ruralis 44 (2): 234-242.

Ploeg, J.D., Marsden, T. 2008. Unfolding webs. The dynamics of regional rural development. Royal Van Gorcum, Assen, The Netherlands.

Ponte, S. 2009. Governing through quality: Conventions and supply relations in the value chain for South African wine. Sociologia Ruralis 49(3): 236-257.

Pugliese, P. 2001. Organic farming and sustainable rural development: A multifaceted and promising convergence. Sociologia Ruralis 41: 112-130.

Rigby, D. Cáceres, D. 2001. Organic farming and the sustainability of agricultural systems. Agricultural Systems 68: 21-40.

Requier-Desjardins, D., Boucher, F., Cerdan, C. 2003. Globalization, competitive advantages and the evolution of production systems: rural food processing and localized agro-food systems in Latin-American countries. Entrepreneurship \& Regional Development Review 15: 49-67.

Sanz, J., Macias, A. 2005. Quality certification, institutions and innovation in local agro-food systems: Protected designations of origin of olive oil in Spain. Journal of Rural Studies 21: 475-486.

Smelser, N.J., Swedberg, R. 1994. Handbook of economic sociology. Princeton University Press, Handbook of Economic Sociology. Princeton, NY.

Solomon, M., Bamossy G., Askegaarg, S., Hogg, M.K. 2006. Consumer behaviour. A European perspective, $3^{\text {rd }}$ Ed. Pearson Education Limited, Essex, England.

Sonnino, R., Marsden, T. 2006. Going local? Regional innovation strategies and the new agrofood paradigm. Journal of Economic Geography 6:181-199.

Streeck, W. 1991. On the institutional conditions of diversified quality production. En: Matzner, E., Streeck, W. (Eds.). Beyond Keynesianism. The socio-economics of production and full employment. Edward Elgar, Aldershot, UK.

Tregear, A., Arfini, F., Belletti, G. Marescotti, A. 2007. Regional foods and rural development: the role of product qualification. Journal of Rural Studies 23:12-22.

Ventura, F., Milone, P., Roest, K. Brunori, G., Miele, M., Menghi, A. 2006. Food Matters revitalising tradition in Italy. En: O'Connor, D., Renting, H., Gorman, M., Kinsella, J. (Eds). Driving rural development: policy and practice in seven EU countries. Royal Van Gorcum, Assen, The Netherlands.

Wierenga, B., Tilburg, A.V., Grunert, K.G., Steenkamp, J.B., Wedel, M. 1997. Agricultural marketing and consumer behavior in a changing world. Kluwer Academic Publishers, Norwell, Massachussetts.

Willer, H., Kilcher, L. 2011. The world of organic agriculture - Statistics and emerging trends. IFOAM, Bonn, Germany.

Wiskerke, J.S., Bock, B., Stuiver, M., Renting, H. 2003. Environmental cooperatives as a new mode of rural governance. Wageningen Journal of Life Sciences 51: 9-25.

Wiskerke, J.S., Ploeg, J.D. 2004. Seeds of transition: Essays on novelty production, niches and regimes in agriculture. Van Gorcum, Assen, The Netherlands. 
